\title{
STOCK LIQUIDITY, FINANCIAL REPORT QUALITY, WEDGE, AND THE PROPENSITY TO PAY DIVIDEND
}

\section{Rahmat Setiawan, Nova Christiana, \& Sanju Kumar Singh}

Department of Management, Faculty Economy and Business, Universitas Airlangga

E-mail: nova.christiana-2015@feb.unair.ac.id

\begin{abstract}
This research examined the effect of stock liquidity on the propensity to pay dividend for 254 Indonesian public listed firms during the period of I 2011 and 2015. Stock liquidity implies transparency level and serves as market monitor for management performance in using the cash flow. Furthermore, this research examines the impact of stock liquidity on dividend payment in the presence of agency conflicts using agency proxies, wedge and government ownership. This paper employed multivariate probit regression. The baseline model has controlled for time in-variant and industry sectors. Robustness checks are employed to present consistent result for other stock liquidity measures. The results confirm the predicted dividend model outcome and prove the contradiction in dividend signaling theory.
\end{abstract}

Keywords: stock liquidity, big four, wedge, dividend, governance, transparency

JEL Classification: [G3, G12, G34, G35]

\begin{abstract}
ABSTRAK
Penelitian ini menguji pengaruh likuiditas saham terhadap kecenderungan membayar dividen untuk 254 perusahaan publik di Indonesia selama periode 2011 dan 2015. Likuiditas saham menunjukkan tingkat transparansi dan berfungsi sebagai pemantau pasar untuk kinerja manajemen dalam menggunakan arus kas. Selanjutnya, penelitian ini meneliti dampak likuiditas saham pada pembayaran dividen di hadapan konflik keagenan menggunakan proxy keagenan, wedge dan kepemilikan pemerintah. Penelitian ini menggunakan regresi probit multivariat. Model dasar telah dikontrol untuk varian waktu dan sektor industri. Cek robust digunakan untuk menyajikan hasil yang konsisten untuk langkahlangkah likuiditas saham lainnya. Hasil mengkonfirmasi hasil model dividen yang diprediksi dan membuktikan kontradiksi dalam teori pensinyalan dividen.
\end{abstract}

Kata kunci: likuiditas saham, empat besar, wedge, dividen, tata kelola, transparansi JEL Classification: [G3, G12, G34, G35] 


\section{INTRODUCTION}

Over the decades, research about dividend has been a fast-growing study all over the world. It is believed that there are no fixed or absolute patterns in how firms will pay dividends (Black, 1976). Some firms may pay dividends; some firms may retain the earning. The seminal works of Miller and Modigliani (MM) (1961) stated that in the perfect market, which some set assumptions such as no transaction cost, no information asymmetry, and riskless investors, impact of dividend is trivial on the firm's value. The value of the firm is solely determined by management's ability in investing firm's assets, which can increase shareholders' wealth. MM explains that shareholders become indifferent toward capital gain or dividend because if firm's stock performs well in the capital market, as indicated by high liquidity traded shares, shareholders can fulfill their liquidity needs by creating low cost homemade dividend. However, if a firm does not perform well, shareholders will be compensated by dividend payment. This results in negative relationship between stock liquidity and dividend payment. Banerjee et al. (2007) have proven this finding through their work on the American stock market about cash dividend and stock liquidity which both work as a substitution.

In the real market circumstances, with a certain level of agency conflict, existence of information asymmetry, and a rational investor, will make dividend to act differently. Hoda and Uno (2011) stated that dividend policy is different for each company and country since they are under different law systems. Allen and Michaely (2003) suggest that dividend is a signal to outsiders; a dominant rationale that explains dividend policy behavior. Their thought is supported by several previous researches, that paying a dividend is a mean to mitigate information asymmetry (Bhattacharya, 1979; John and Williams, 1985; Miller and Rock, 1985). However, when the study is conducted in the emerging market, as have been done by Li and Zhao (2008), Lin et al. (2016), and Jiang et al. (2017), the findings show an inconsistency with the dividend signaling theory, and instead shows inverse correlation between information asymmetry and dividend policy. Firms with a high-level of information asymmetry will less likely to pay a dividend, compared with firms with low-level of information asymmetry. There, the dividend is an outcome of good corporate governance and dividend payment seems to not act as a mean to mitigate information asymmetry in the emerging market (Lin et al., 2016).

Corporate payout is closely related to the legal aspect and corporate governance (Mitton, 2004). La Porta et al. (2000b) have formulated two models of dividend; outcome model and substitution model, and both models are based on the governance environment of the firm. Outcome model explains that dividend payment is an outcome of improved firm's governance, while substitution model explains that the dividend payment is a substitution or compensation initiated by a firm, and is an effort to show good reputation and indicate no 


\section{Rahmat Setiawan \\ Nova Christiana \\ Sanju Kumar Singh}

expropriation acts in the firm, in order to gain external financing. Reputation is important for firms since it is a way to get external financing (Gomes, 2000). It is also widely acknowledged that dividend policy is determined by the severity of agency issue (Saadi and Dutta, 2009). Gugler and Yurtoglu (2003) stated that when dividend is paid, it signals agency problem in the firm. Previously, Easterbrook (1984) implied that firm's policy to pay a dividend would reduce insider's incentive to expropriate the minority. Jensen (1986) added that by paying a dividend, it would reduce the insider's ambition for negative investment and other overspendings. So, it clearly shows that dividend payment is a mean to mitigate the agency problem of the firms. Previous studies on dividends have used dividend as an explanatory variable for some firms' factors such as stock price (Litzenberger and Ramsaswamy, 1982) or firms' value (Fama and French, 1998).

This study examined the impact of stock liquidity, as a part of market microstructure, on corporate payout policy. Lipson (2003) argued that market microstructure is able to shape corporate policy. In this current study, dividend payout is one of corporate policy which is believed to not only be affected by firm's characteristics, but is also affected by the market's mechanism. Previous researches have used firm's characteristics as explanation for dividend payout such as Fama and French (2001), Denis and Osobov (2008), while Rozeff (1982), Easterbrook (1984), Holmstorm and Tirole (1993) argue that a capital market is a monitor for firm's management on how they will use the cash flow. Using firm's characteristics as the only explanatory variable will neglect the informational effect of stock liquidity on dividend policy, then this research is relevant to be done in order to prove that stock liquidity has a positive impact on dividend payout policy.

The research about dividend has been a fast-growing subject, and since it was a puzzle, there is no absolute pattern about how and what factors are the keys of dividend policy (Black, 1976). Stock liquidity is a part of market microstructure which has an informational effect (Kyle, 1984; Kyle, 1985). The rationale of this thought is explained as follows. Outside investors' institution, investors are able to assess the firm, and whether it's good or bad (Allen et al., 2000). Easterbrook (1984), Holmstorm and Tirole (1993), external monitoring is effective in monitoring the internal. In the transparent environment, the misuse of cash flow for private benefit will likely be detected (Li and Zhao, 2008; Petrasek, 2012).

This paper used Indonesian firms as samples, listed on Indonesian Stock Exchange (hereafter: IDX) between 2011 and 2015. Employing the period of time is believe that the economy circumstance in Indonesia was quite stable and will not bias the result. Jiang et al. (2017) argued that the impact of stock liquidity on dividend payout will be stronger when it is tested 
on the emerging market with high information asymmetry and severe level of agency problems. Indonesia is concluded as one of the emerging markets based on several phenomena, which appear clearly in most of the Indonesian firms, and also in the legal aspect and institutions. First, Indonesia is under the civil law system. Based on La Porta et al. (2000b), civil law countries tend to pay lower dividend than common law countries. Second, Indonesia follows a two-tier board system, but the two-tier board system implementation is unlike other countries that follow the same system. There is no legal representative of employees. These describe some kind of governance issues existing in the management. Third, Claessens et al. (2000) found that two-thirds of Indonesian firms are concentrated firms and family controlled firms. Concentrated firms often give inevitable agency problems. Attig et al. (2006), showed that concentrated ownership often limit their disclosure, then exploited the minority through it (Bae et al., 2002).

Interestingly, Lesmond (2005) stated that emerging market experiences a tremendous growth of market liquidity, due to the rationale that emerging market promised high return, and this attracts foreign investors. In Indonesia, the market experienced a high growth market capitalization when the Surabaya Stock Exchange (BES) and Jakarta Stock Exchange (BEJ) merged in 2007 . Rhee (2009) reported in his paper that $70 \%$ of the ownership or about $41 \%$ of the total market capitalization in Indonesian market are dominated by foreign investors in the form of institutions such as banks, mutual funds, insurance companies, pension funds, and brokerages. Institution investors tend to trade in the large amount, keep liquid stocks in their portfolios, and avoid illiquid assets (Cooper et al., 1985). These sophisticated investors are able to detect the firm's quality, and thus will invest only on firms with low agency issue, as shown through dividend payment (Allen et al., 2000). By these arguments, specifically, this study contributes and can be an insight to investors about the Indonesian market. It explicitly shows how the presence of institutional investors can be a parameter for firms' good quality and low level of agency problems. Thus, this study can be an input for the firms as well, to improve their governance through enhancing the stock liquidity, which also increases the informational side of the stock price.

Some previous studies yielded different results; even if some studies were conducted in the emerging market, or even conducted at the same capital market, it still did not give a consistent result. For example, a similar study of dividend policy in the Indonesian market by Sawitri and Sulistyowati (2018), which used different methodology from this study, showed negative impact of stock liquidity on dividend policy. Previous study by Banerjee et al. (2007) on the American market showed a negative impact of stock liquidity on the dividend policy. Subsequently, several studies conducted in the emerging market done by Michaely and Qian (2016), Jiang et al. (2017), Strerenczak (2018), all showed positive impact of stock 


\section{Rahmat Setiawan \\ Nova Christiana \\ Sanju Kumar Singh}

liquidity on dividend policy. By these arguments, this paper contributes to several current papers with the subject of corporate finance dividend policy in the agency and governance framework. Edwards (1984) stated that each investor has different investment purposes. This implies that not all investors are in the same circumstances as what MM (1961) mentioned before, and MM's cannot be a general explanation for all capital markets. That is what makes dividend matters.

\section{LITERATURE REVIEW}

\section{The impact of stock liquidity on dividend policy}

Stock liquidity is widely believed as a baffling concept since there is no direct method to measure it (Kyle, 1985). Alan et al. (2009) described liquidity is the ability of a stock to be traded in a certain time without affecting the price in a significant amount. Spread has been a common measure of stock liquidity. Liquidity contains three elements, depth, tightness (spread), and resiliency (Kyle, 1985). These elements then give informational side to liquidity, which is often missed from observations. Based on Kyle (1984), Kyle (1985), liquid stock will ease informed traders in trading and disguising their activities on private information-based trading. When an informed trading occurred, it means informed trader trades using private information, and the marginal value of information increased (Holmstorm and Tirole, 1993). This makes speculators try to get more information they need for their trading purpose. They can take on advantageous position and gain return when they trade with uniformed trader. Since the informed trader cannot detect whether they trade with informed trader or not, they compensate for the potential loss by raising the spread. Thus it is implicitly shown that the bigger the spread, the higher the information asymmetry.

Deshmukh (2005) stated that dividend in the imperfect market is determined by agency problem, information asymmetry level, and transaction cost. Mitton (2004) suggested that transparency is a factor of firm's governance. Outsider's monitoring can increase transparency. Holmstorm and Tirole (1993) suggested that the market is a monitor for the firm's management on how they will use the cash flow. Insiders always face the choice of distributing or to retaining surplus earnings. Jensen (1986) stated that paying dividend has a purpose to reduce insider's opportunity in misusing cash flow for private benefit. Jensen and Meckling (1976) and Faccio et al. (2001) have labeled this act as expropriation. In the circumstance with high level of information asymmetry, which leads to low transparency, using cash flow for private benefit will less likely be detected (Stiglitz, 2000; Leuz et al., 2003). While in the circumstance with low level of information asymmetry, which leads to high transparency, using cash flow for private benefit will more likely be detected (Li and Zhao, 2008; Petrasek, 2012). When outsiders found that a firm does not distributes the surplus 
earnings to shareholders, it will hurt firm's reputation since it is a signal to the outsiders that the firm has no commitment in minimizing or overcoming the expropriation (Gomes, 2000). Firms need a good reputation because good reputation is a way of gaining external financing (Gomes, 1996), since not all go-public firms have good governance (Gomes, 2000). Claessens and Fan (2002) suggested that when corporate transparency is low, the agency problem is exacerbated. Low transparency relates to low governance. The previous findings viewed dividend as an outcome of good governance. Good governance comes from the market that plays a role in monitoring insider's behavior in using the cash flow. Based on these arguments, the hypothesis is arranged as follows:

\section{$H_{1}$ : Liquid stock, which reflects high transparency effect, has a positive effect on the firm's propensity to pay a dividend.}

\section{The impact of financial reporting quality on dividend policy}

Claessens and Fan (2002) and Fan and Wong (2002) agreed that public companies in East Asia have low disclosure quality and low transparency, and Indonesia is one of them (Mulyani et al., 2016). Mitton (2002) stated that good quality firms usually have the big six (the four members of this big six is big four in this study) as their external auditors. Faccio et al. (2001) mentioned that transparency is an important quality for the shareholders. For example, transparent firms will enable shareholders to trace the ownership chain and find the ultimate owner of the firms, and then they can figure how much expropriation impact they might bear. Corporate reports are sources of information. Enhancing the quality of reporting helps to reduce information asymmetry since reputable auditing firms audited the repots (Fan and Wong, 2002; Fafatas and Sun, 2010). Big Four's members are believed to be able to detect wrong accounting practice that does not match with the official standard (Becker, 1998). Previous research by Luo and Chen (2002) used Big Four as the measure of financial reports' quality, showing a negative relationship with agency cost. Firms with less severe agency problem will have a propensity to pay dividend. Based on the arguments, the hypothesis is arranged as follows:

H2: The financial reporting quality has a positive effect on the firm's propensity to pay dividend.

\section{The impact of wedge on the dividend policy}

A wedge ${ }^{1}$ is a gap between control right and cash flow right in the ultimate ownership structure (Claessens et al, 2002). Jensen and Mecking (1976) mentioned that agency

IIn the ultimate ownership (Claessens et al., 2002), control right is obtained from the total of the direct and minimum indirect of ownership proportion owned along of the shareholding chain. Cash flow right obtained from the total of direct and indirect ownership. Indirect ownership for cash flow right is the product of the ownership along the shareholding chain. 


\section{Rahmat Setiawan \\ Nova Christiana \\ Sanju Kumar Singh}

problem appears when cash flow right and control right are separated. Controlling shareholders have a big incentive to exploit the minority if they hold a bigger cash flow right than controlling right (Gugler and Yurtoglu, 2003, DeCesari, 2012). This kind of agency problem appears in the pyramid and cross-holding ownership structure (La Porta et al., 1999; Faccio et al., 2001). Claessens et al. (2000), find that most of the firms in East Asia, like Indonesia, have a higher cash flow right than European countries. Based on these previous findings, firms with a higher level of cash flow right than control right have a big incentive in expropriating their minority. This resulted in negative relationship between the wedge and dividend policy. The hypothesis of wedge's impact on dividend is arranged as follows:

\section{$\mathrm{H}_{3}$ : The wedge between control rights and cash rights causes a negative effect on the firm's propensity to pay dividend.}

\section{METHODS}

This research uses Indonesian firms listed in Indonesia Stock Exchange (hereafter: IDX) from 2011 to 2015. 254 firm samples are engaged in this study and generating about 1266 observations. The descriptive statistics are available in table 1. The dependent variable in this study is payout policy, specified as dividend propensity to pay (DPP). Since DPP is a dichotomous variable, 1 for payer firm and 0 otherwise, multivariate probit regression and marginal effects are conducted to estimate the baseline model. Duygun et al. (2018) have used the same method in examining the dividend policy in Indonesian market. Independent variables employed in this study are stock liquidity (SLIQ), external auditor firms in Indonesia that are affiliated by international "Big Four", and the gap of control rights and cash flow rights by La Porta et al. (1999).

Then, we controlled for factors that significantly affect the corporate payout. Fama and French (2001) stated that payer firms are firms that have big size, cash potential, and high profitability. So, the firm's size, cash liquidity, and profitability are respectively controlled by SIZE, CASH, and ROA variables. Firms with high investment opportunity tend to retain their income rather than to distribute it to the investors (Lang and Litzenberger, 1989; Smith and Watts, 1992). Similarly, Barclay et al. (1995) stated that dividend payout is largely determined by the investment opportunity, therefore making dividend payment low for firms with high growth opportunity. Growth and investment opportunity of the firms are controlled by TOBINSQ variable. Rouzeff (1982) stated that having external financing is costly; thus firms will prioritize the cash to fulfill the debt obligation over disbursing cash to the shareholders, making the relationship between leverage and dividend negative. Setiawan et al. (2016)

For example, Mr. Y owns $24 \%$ of control right $(4 \%+(=\min (20 \%, 30 \%))$ and $10 \%$ of cash flow right $(4 \%+$ $(=20 \% \times 30 \%))$. So, that the wedge is $14 \%(=24 \%-10 \%)$. 
have proven that leverage has a negative impact on Indonesian firms. For these arguments, the leverage level is controlled by LEV variable. Claessens et al. (2000) found that most Indonesian firms are family-concentrated firms and family has positions on the top management. This ownership structure model invokes more expropriation to the minority (La Porta et al., 2000a). Controlling shareholders demand more dividends in some regulated emerging markets (Chen et al, 2009; Huang et al., 2011; Guo, 2016) such as in Indonesia (Sari and Baridwan, 2014). This resulted in positive relationship between controlling shareholders and dividend policy. Independent board is the main part of the firm that also affects the dividend policy. Based on previous findings by La Porta et al (2000a), Faccio et al. (2001), Indonesia has severe agency problems. U.S. Senate research (2002) also found that the independent boards are mostly persons with long tenure in the firms, affiliating them with the management, thus making the governance not too effective since they are timid to challenge the management. This resulted in negative relationship between independent board and dividend policy. The independent board will be controlled by IndepBoard variable. Based on the previous explanations and these arguments, the research model is arranged below. There are variations that may affect the result, as a result of time-invariant and industry sector. So, these factors are also controlled in the baseline model.

$$
D P P_{i, t+1}=\alpha_{i, t}+\beta_{i, t} \text { Stock Liquidity }_{i, t}+\beta_{i, t} \text { Big }_{i, t}+\beta_{i, t} \text { Wedge }_{i, t}+\gamma_{i, t} \text { Controls }_{i, t}+\varepsilon_{i, t}
$$

\section{RESULTS AND DISCUSSION}

Figure 1 shows the trend of dividend payout ratio of 254 sample firms between 2011 and 2015. Based on the figure, consumer goods sector is the highest payout ratio sector, followed by mining sector. Property sector and agriculture sectors are the two lowest payout ratio sectors. Table 2 presents the distribution of sample firms based on industry sectors. Trade and service is the largest proportion of all, about 315 firms (24.80\%). Second largest proportion is basic industry and chemicals with 245 firms (19.29\%). The agriculture sector is the smallest portion with 45 firms (3.54\%). In column 6 shows the proportion of dividend payer firms of each sectors. The agriculture sector is the sector with the highest proportion of payer firms (71.11\%). Second largest is property, real estate and building construction (56.95\%). Last column shows the proportion of payout ratio of each sectors. The consumer goods has the highest payout ratio of all sectors, about $30.47 \%$ of the total incomes are distributed as cash dividend.

Table 3 describes the descriptive statistics of variables used in this study on Indonesian IDX listed firms in 2011 and 2015. Based on the result, the DPP's Means $=.51$. This shows that $51 \%$ of the samples are the dividend payer firms. The standard deviation ( $S D=.5$ ) suggests that the dispersion of firms paying dividend is moderate among firms. Stock liquidity (SLIQ) among 


\section{Rahmat Setiawan \\ Nova Christiana \\ Sanju Kumar Singh}

firms in Indonesia is quite dispersed and low, as shown by SLIQ variable ( $M=-.04, M d n=-.001$, $S D=.114)$. The quality of financial reporting (BIG4) shows about $40 \%$ of the firms in the sample research uses Big4 ( $M=.42, S D=.49)$. This result is also supported by the table 4 of the number of firms audited by big four. This result indicates that almost $50 \%$ of the firms' samples are audited by the high reputable auditing firm. Then, other findings show that the agency conflict phenomenon in this research sample. WEDGE variable shows $M=.76$ and $S D=.43$. Indicates that higher gaps between control right and cash flow right of firms in the sample research means higher agency problems. Agency problem from the overinvestment side is shown by TOBINSQ $M=.99$ and $S D=.15$. This indicates that the overinvestment in the sample firms is relatively fair. Governance variable is INDEP shows $M=.11$ and $S D=.14$, indicating that the number of the independent variable in the firms are relatively low. The size of the firm sample is showing a big variance but samples are dominated by the big size firms. This is shown by the SIZE'S $M=14.65 ; M d n=14.60$ and $S D=1.66$. The firms in the sample are relatively bear a big debt and having low cash liquidity. These are shown by the LEV'S $M=.51$ and SD $=.67$ and CASH'S $M=.10$ and $S D=.11$. CTRL is controlling variable, showing $M=.47$ and $S D=$ .23. This indicates that averagely the controlling shareholders of firms in the sample are $47 \%$.

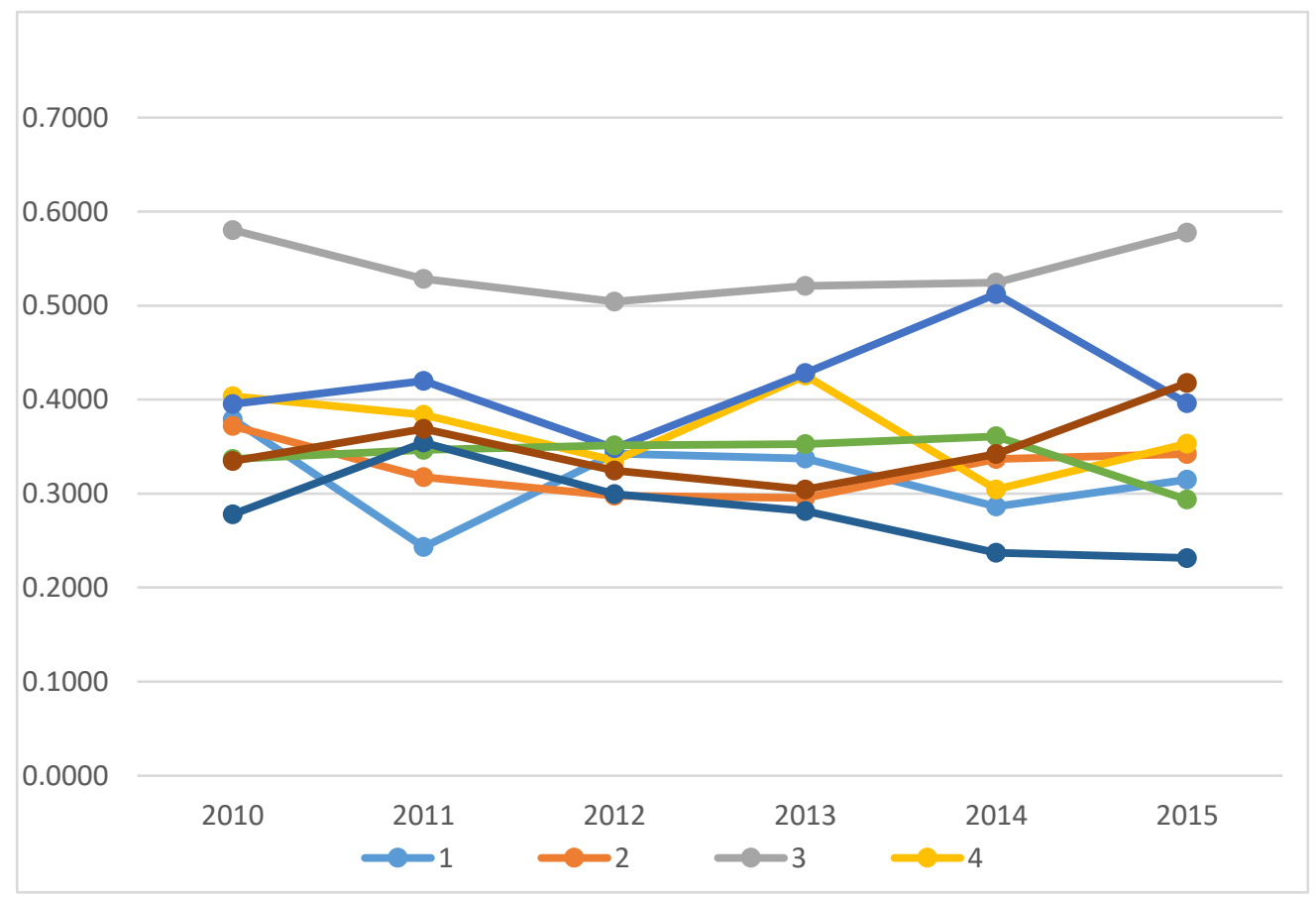

Figure 1.

The Payout Ratio Trend of Sample firms 2010-2015

Table 5 shows the spearman correlation. SLIQ has positive and significant correlation to DPP $r(1264)=.23, p<.01$. BIG4 shows the correlation to DPP is $r(1264)=.312$ and significant $(p<$ $.01)$. The results support the agency problem exists in the firm sample. As expected, WEDGE 
variable has negative and significant correlation to the DPP $r(1264)=-.05, p<.01$. The other agency problem is derived from high overinvestment firms shown by control variable TOBINSQ. Based on Lang and Litzenberger (1989), Tobin's $Q$ is an indicator of overinvestment. Overinvestment firms tend to have a low dividend payment, firms exploit the resource to fund the investment rather than paying the dividend then making the relationship between investment opportunities and dividend policy negative. The result shows TOBINSQ correlation negative $r(1264)=-.22$ and significant $(p<.01)$. Other controls show positive correlation to the DPP, such as SIZE $(r(1264)=.37, p<.01)$, CASH $(r(1264)=.40, p<.01), \operatorname{CTRL}(r(1264)=.22, p<$ $.01)$. Other controls show negative correlation to the DPP, such as LEV $(r(1264)=-.12, p<.01)$ and INDEP $(r(1264)=-.09, p<.01)$.

\section{Table 1.}

Variable definitions

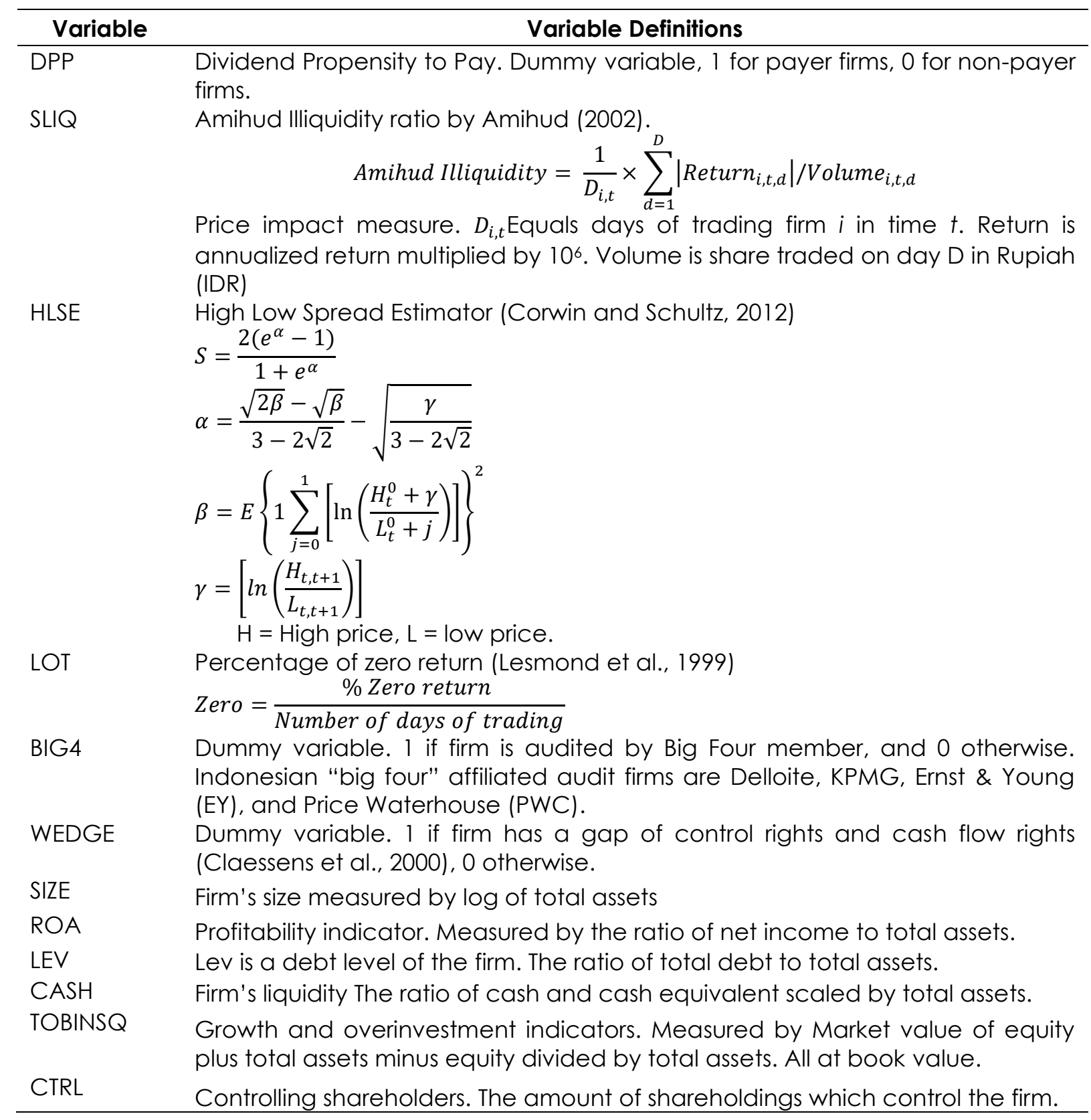


Table 2.

Sample based on industry sectors

\begin{tabular}{|c|c|c|c|c|c|c|c|}
\hline $\begin{array}{l}\mathbf{N} \\
\mathbf{0}\end{array}$ & Industry sectors & Payer & $\begin{array}{l}\text { Non- } \\
\text { Payer }\end{array}$ & $\begin{array}{l}\text { Number } \\
\text { of firms }\end{array}$ & $\begin{array}{c}\text { Proportion } \\
\text { of firms } \\
(\%)\end{array}$ & $\begin{array}{c}\text { Proportion } \\
\text { of payers } \\
(\%)\end{array}$ & $\begin{array}{c}\text { Mean of } \\
\text { dividend } \\
\text { payout } \\
\text { ratio (\%) }\end{array}$ \\
\hline 1 & Agriculture & 32 & 13 & 45 & 3.54 & 71.11 & 23.6 \\
\hline 2 & $\begin{array}{l}\text { Basic industry and } \\
\text { chemicals }\end{array}$ & 115 & 130 & 245 & 19.29 & 46.94 & 15.6 \\
\hline 3 & $\begin{array}{l}\text { Consumers good } \\
\text { Infrastructure, }\end{array}$ & 78 & 62 & 140 & 11.02 & 55.71 & 30.47 \\
\hline 4 & $\begin{array}{l}\text { utilities, } \\
\text { transportation }\end{array}$ & 34 & 56 & 90 & 7.07 & 37.78 & 14.29 \\
\hline 5 & Mining & 55 & 65 & 120 & 9.45 & 45.83 & 19.75 \\
\hline 6 & $\begin{array}{l}\text { Miscellaneous } \\
\text { Property, real }\end{array}$ & 74 & 76 & 150 & 11.81 & 49.33 & 16.37 \\
\hline 7 & $\begin{array}{l}\text { estate, building } \\
\text { construction }\end{array}$ & 94 & 71 & 165 & 12.99 & 56.97 & 15.42 \\
\hline \multirow[t]{2}{*}{8} & $\begin{array}{l}\text { Trade, services, } \\
\text { and investment }\end{array}$ & 163 & 152 & 315 & 24.80 & 51.75 & 18.25 \\
\hline & Total & 645 & 625 & 1270 & 100 & & \\
\hline
\end{tabular}

Table 3.

Descriptive Analysis

\begin{tabular}{lcrrrrrrr}
\hline Variable & Mean & \multicolumn{1}{l}{ SD } & \multicolumn{1}{c}{ P10 } & P25 & \multicolumn{1}{c}{ P50 } & P75 & P90 & N \\
\hline DPP & 0.508 & 0.500 & 0 & 0 & 1 & 1 & 1 & 1270 \\
SLIQ & -0.040 & 0.114 & -0.095 & -0.016 & -0.001 & -0.00001 & -0.0000002 & 1270 \\
BIG4 & 0.422 & 0.494 & 0 & 0 & 0 & 1 & 1 & 1270 \\
WEDGE & 0.761 & 0.427 & 0 & 1 & 1 & 1 & 1 & 1266 \\
SIZE & 14.65 & 1.66 & 12.49 & 13.41 & 14.60 & 15.84 & 16.77 & 1266 \\
CASH & 0.100 & 0.105 & 0.009 & 0.025 & 0.064 & 0.140 & 0.253 & 1266 \\
LEV & 0.512 & 0.675 & 0.185 & 0.300 & 0.480 & 0.630 & 0.770 & 1266 \\
TOBINSQ & 0.985 & 0.152 & 0.800 & 0.889 & 0.999 & 1.073 & 1.146 & 1266 \\
CTRL & 0.478 & 0.229 & 0.175 & 0.292 & 0.486 & 0.636 & 0.805 & 1266 \\
INDEP & 0.105 & 0.140 & 0.000 & 0.000 & 0.000 & 0.200 & 0.333 & 1266 \\
\hline
\end{tabular}

Table 4.

The Number of Firms Audited by Big Four

\begin{tabular}{llllll}
\hline $\mathbf{2 0 1 1}$ & $\mathbf{2 0 1 2}$ & $\mathbf{2 0 1 3}$ & $\mathbf{2 0 1 4}$ & $\mathbf{2 0 1 5}$ & Total \\
\hline 103 & 106 & 109 & 108 & 110 & 639 \\
\hline
\end{tabular}


Table 5.

Spearman correlation

\begin{tabular}{|c|c|c|c|c|c|c|c|c|c|c|}
\hline & DPP & SLIQ & WEDGE & BIG & SIZE & LEV & CASH & TOBINSQ & CTRL & INDEP \\
\hline DPP & 1 & & & & & & & & & \\
\hline \multirow[t]{2}{*}{ SLIQ } & 0.213 & 1 & & & & & & & & \\
\hline & $0.000 * * *$ & & & & & & & & & \\
\hline \multirow[t]{2}{*}{ WEDGE } & -0.049 & -0.007 & 1 & & & & & & & \\
\hline & $0.084 *$ & 0.809 & & & & & & & & \\
\hline \multirow[t]{2}{*}{ BIG4 } & 0.312 & 0.174 & -0.005 & 1 & & & & & & \\
\hline & $0.000 * * *$ & $0.000 * * *$ & 0.874 & & & & & & & \\
\hline \multirow[t]{2}{*}{ SIZE } & 0.368 & 0.354 & -0.005 & 0.428 & 1 & & & & & \\
\hline & $0.000 * * *$ & $0.000 * * *$ & 0.847 & $0.000^{* * *}$ & & & & & & \\
\hline \multirow[t]{2}{*}{ LEV } & -0.124 & -0.067 & 0.006 & -0.050 & 0.081 & 1 & & & & \\
\hline & $0.000^{* * *}$ & $0.017^{* *}$ & 0.823 & $0.077^{*}$ & $0.004^{* * *}$ & & & & & \\
\hline \multirow[t]{2}{*}{$\mathrm{CASH}$} & 0.400 & 0.153 & -0.093 & 0.143 & 0.181 & $\begin{array}{c}-0.258 \\
0.000\end{array}$ & 1 & & & \\
\hline & $0.000^{* * *}$ & $0.000 * * *$ & $0.001^{* * *}$ & $0.000^{* * *}$ & $0.000^{* * *}$ & $* * *$ & & & & \\
\hline \multirow[t]{2}{*}{ TOBINSQ } & -0.215 & -0.221 & -0.021 & -0.146 & -0.250 & $\begin{array}{c}-0.113 \\
0.000\end{array}$ & $\begin{array}{r}-0.111 \\
0.000\end{array}$ & 1 & & \\
\hline & $0.000^{* * *}$ & $0.000 * * *$ & 0.448 & $0.000 * * *$ & $0.000 * * *$ & $* * *$ & $* * *$ & & & \\
\hline \multirow[t]{2}{*}{ CTRL } & 0.216 & 0.031 & -0.066 & 0.206 & 0.098 & 0.028 & $\begin{array}{l}0.102 \\
0.000\end{array}$ & -0.11 & 1 & \\
\hline & $0.000^{* * *}$ & 0.267 & $0.018^{* *}$ & $0.000 * * *$ & $0.000 * * *$ & 0.320 & $* * *$ & $0.000 * * *$ & & \\
\hline \multirow[t]{2}{*}{ INDEP } & -0.094 & 0.013 & 0.063 & -0.055 & -0.020 & -0.011 & -0.066 & 0.03 & 0.000 & 1 \\
\hline & $0.000 * * *$ & 0.654 & $0.024^{* *}$ & $0.049^{* *}$ & 0.481 & 0.686 & $0.019^{* *}$ & 0.339 & 0.99 & \\
\hline
\end{tabular}

*** Sig. 1\%, ** Sig. 5\%, * Sig. 10 
Table 6.

Probit Estimation Result of stock liquidity to the propensity to pay dividend

\begin{tabular}{lcc}
\hline Dep. Var: DPP & Coef. & $\mathbf{z}$ \\
\hline Intercept & $-2.644^{* * *}$ & -4.29 \\
SLIQ & $1.230^{* * *}$ & 2.43 \\
Non-BIG4 & $-0.482^{* * *}$ & -5.42 \\
WEDGE & $-0.163^{*}$ & -1.81 \\
SIZE & $0.292^{* * *}$ & 9.82 \\
LEV & -0.116 & -1.41 \\
CASH & $0.044^{* * *}$ & 8.27 \\
TOBINSQ & $-1.061^{* * *}$ & -3.62 \\
CTRL & $0.449^{* * *}$ & 2.45 \\
INDEP & $-0.625^{* *}$ & -2.03 \\
Pseudo-R & & \\
N & & 0.2596 \\
*** Sig. 1\%, ${ }^{* *}$ Sig. 5\%, ${ }^{*}$ Sig. $10 \%$ & 1270 &
\end{tabular}

Table 7.

The Effects of Financial Report Quality and Wedge on the Propensity to Pay Dividend

\begin{tabular}{lcc}
\hline & Predicted likelihood & $\mathbf{z}$ \\
\hline Big Four & $0.596^{* * *}$ & 29.61 \\
Non Big Four & $0.448^{* * *}$ & 26.73 \\
Wedge & $0.498^{* * *}$ & 36.40 \\
No Wedge & $0.545^{* * *}$ & 24.96 \\
\hline
\end{tabular}

*** Sig. $1 \%,{ }^{* *}$ Sig. $5 \%, *$ Sig. $10 \%$

Table 6 shows the probit estimation result. SLIQ is positive and significant $(\beta=1.23, z=2.43, p<$ .05), means that stock liquidity price impact has a positive effects on dividend payout policy. The untabulated marginal effect ${ }^{2}$ shows that, if all variables being equal, increase of one unit of stock liquidity will increase the propensity to pay dividend by about $51.7 \%$. Non-BIG4 is negative and significant $(\beta=-.48, z=-5.42, p<.01)$. This means that BIG4 does impact the corporate propensity to pay dividend. Firms that are not audited by BIG4 firms have low propensity to pay dividend, as shown in table 7 of marginal effects. Given that all variables remain equal to mean values, the propensity of firms audited by BIG4 firms to pay dividend is $60 \%(p<.01)$. The result implies that the better the financial reporting quality, the bigger the propensity of the firms to pay dividend. WEDGE is negative and significant $(\beta=-.163, z=-1.81$, $p<.1)$. This means that wedge impacts corporate payout policy. Firms with a gap in their control rights and cash flow rights tend to have low propensity to pay dividend. In table 7 ,

2Probit marginal effect can be checked in the appendix 1. 
the marginal effect of Wedge on dividend payout is $50 \%$, given all variables remain equal to mean values. The result implies that when the firm's agency problem is high, the lower the propensity of the firm to pay dividend.

Table 8.

Alternative Measure of Stock Liquidity

\begin{tabular}{|c|c|c|c|c|}
\hline \multirow[b]{2}{*}{ DPP } & \multicolumn{2}{|c|}{ HSLE } & \multicolumn{2}{|c|}{ LOT } \\
\hline & Coef. & $z$ & Coef. & z \\
\hline Intercept & $-2.611^{* * *}$ & -4.23 & $-1.998 * * *$ & -3.15 \\
\hline Stock Liquidity & $7.203 * *$ & 2.24 & $0.242 * * *$ & 4.18 \\
\hline Non-BIG4 & $-0.480 * * *$ & -5.36 & $-0.547^{* * *}$ & -6.13 \\
\hline Non-WEDGE & $-0.174 *$ & -1.92 & -0.126 & -1.39 \\
\hline SIZE & $0.304^{* * *}$ & 10.23 & $0.259 * * *$ & 8.33 \\
\hline LEV & -0.121 & -1.45 & -0.120 & -1.48 \\
\hline $\mathrm{CASH}$ & $0.046^{* * *}$ & 8.39 & $0.046^{* * *}$ & 8.63 \\
\hline TOBINSQ & $-1.170^{* * *}$ & -3.92 & $-1.120 * * *$ & -3.81 \\
\hline CTRL & $0.415^{* *}$ & 2.26 & $0.551^{* * *}$ & 3.04 \\
\hline INDEP & $-0.652 * *$ & -2.12 & $-0.742 * *$ & -2.40 \\
\hline Pseudo-R22 & \multicolumn{2}{|c|}{0.259} & \multicolumn{2}{|c|}{0.268} \\
\hline$N$ & \multicolumn{2}{|c|}{1270} & \multicolumn{2}{|c|}{1270} \\
\hline
\end{tabular}

*** Sig. 1\%, ${ }^{* *}$ Sig. 5\%, * Sig. 10\%

Table 8 is showing the robustness check of alternative measures of stock liquidity. The results show that HSLE's impact on the propensity to pay dividend is positive and significant $(\beta=7.2$, $z=2.24, p<.05)$. LOT also gives the same result, positive and significant $(\beta=0.24, z=4.18, p<$ $.01)$. The result is consistent that the firm with liquid stock will have higher propensity to pay dividend than firms with illiquid stock. The result robust across alternative measures of stock liquidity. Then, other variables such as non-BIG4 are negative and significant for both columns HSLE $(\beta=-0.48, z=-5.36, p<.01)$ and LOT $(\beta=-0.55, z=-6.13, p<.01)$ of its impact on the propensity to pay dividend. While, non-WEDGE is $(\beta=-0.17, z=-1.92, p<.1)$ only negative and significant on the column HSLE of its impact on the propensity to pay dividend.

This study first of all proves that firms in Indonesian market suffer with agency problem. The descriptive statistics results show that about $76.1 \%$ of Indonesian firms have a high concentration of cash flow. The big gap between the controlling rights and cash flow rights indicates an agency problem in financial aspect. The big concentration makes insiders have the bigger incentive to exploit the company resources for their private benefit, such overspending and investing in the unprofitable project to expand the business empire so the manager will gain more incentive. However, at the other side, the overinvestment among firms in Indonesian market is relatively moderate, 0.99 . This should be noticed that if the 


\section{Rahmat Setiawan \\ Nova Christiana \\ Sanju Kumar Singh}

agency problem is high, showing the overinvestment is also high $(Q>1)$. Other findings show corporate governance aspect such as Independent board. Independent board of Indonesian firms are relatively small. It is about $10.5 \%$ of independent board in the firms. The findings also show that the negative relationship between independent board to the propensity to pay dividend. This means, that even though firm owns independent boards, they tend to act negatively about the dividend policy. Indonesian firms bear a high debt ratio to the total assets (51.2\%). This board will make sure that firm will make priority to fulfill the debt obligation than to work in behave on minority shareholders. Most of the Indonesian firms have independent board start from 2014. These boards are them who are previously served the company as other directors than appointed by the company general assembly as independent board. This is making the independent board does not work effectively as one who protect the minority interest since they have strong affiliation with the insiders. They will become timid in confronting the insiders. Even though half of the sample firms in the Indonesian market are able to pay dividend, shown by the firms size and the mean of propensity to pay dividend, these firms suffer with low cash liquidity. The result shows that the cash on hand of Indonesian firms are relatively low, only $10 \%$. In this study, the large shareholders gives a positive impact on the Indonesian firm's dividend policy. This findings confirms La Porta et al. (1999) that in Indonesia's context, large shareholders usually a group of owner which recognized by the same family name. They have a big incentive in supervising the managers, making managers will behave as majority shareholders interest. For instance, to disburse cash as a dividend.

This study proves that the price impact, as a measure of stock liquidity, gives a positive impact on the dividend payout policy. The finding also robust in other alternative measures of stock liquidity (HSLE and LOT). The findings prove the inversion of signaling dividend theory. Signaling dividend theory states that insiders have more access to the information than the outsiders. So, when the asymmetry information high, the company will convey the signal outside through dividend payment. Rather, in our estimation proves that the higher asymmetry information, shown by illiquid stock, making insiders have a big incentive not to pay dividend. On the contrary, firms with a high stock liquidity will pay the dividend to the shareholders. Firms always face a cost and benefit about dividend policy, but since these firms are go public firms, having a good reputation is important in order to gain funding from external. Firms need to show to the public that they have a commitment in overcoming expropriation through dividend policy. This result proves that good corporate governance and well market monitoring are the ultimate factors which affecting corporate payout policy. This finding is supported by the other finding that firms with bigger gap or wedge tend not to pay dividend. In the company's governance side, it is important to alleviate the error 
of financial information contents. The quality of financial reporting which audited by the Big Four affiliation are considered as big quality and high assurance financial reports. Result shows that the non-Big Four firms tend not to pay dividend compared with firms which audited by Big Four affiliation auditor firms. Big four considers as auditor firms which can assure that the reports are no error and follow the accounting standard.

\section{CONCLUSION}

This study examined the impact of stock liquidity on corporate payout policy in Indonesian firms listed on Indonesian Stock exchange between 2011 and 2015. The propensity to pay dividend is specified as a response variable in the model with several explanatory variables used; stock liquidity as the measure of market environment governance and information asymmetry proxy, Big Four as the quality of financial reports, and wedge as the gap between cash flow right and control right. The specified model has also controlled for other factors that affect the corporate payout such as the size of the firm, leverage ratio, cash liquidity, profitability, growth and investment opportunity, independent board, and controlling shareholders. Industry and time-invariant variables are also controlled, which potentially affect the result.

The result confirms the outcome of dividend model by La Porta et al. (2000b) that dividend is an outcome of improved governance environment, and it also proved the inverse of dividend signaling theory. Amihud (2002) Illiquidity measure is a price impact measure has proved that stock liquidity gives a positive impact on the dividend policy in Indoneisa as one of the emerging market countries. This confirmed previous findings such as Li and Zhao (2008), Lin et al. (2016), and Jiang et al. (2017), which have conducted similar study in the emerging market that proved a positive relationship between stock liquidity and dividend policy. It is empirically shown that there is a significant impact of information asymmetry on the firm's dividend policy. Firms with high-level information asymmetry have a low propensity to pay dividend. The quality of financial reports, using "Big Four" as a proxy, has a positive effect on the firm's propensity to pay dividend. Big four members is empirically (Fan and Wong, 2002; Luo and Chen, 2002) and widely believed as reputable external auditors and can enhance the quality of the reporting.

There are about $42 \%$ of the firms in the sample were audited by Big Four between 2011 and 2015. The wedge of cash flow right and control right gives a negative impact on the firm's propensity to pay dividend. From the descriptive statistics, most Indonesian firms have heavy cash flow concentration. About $76 \%$ of the firms in the sample are cash flow concentrated firms. The agency issue is very obvious and inevitable in most Indonesian firms. The results on effect of stock liquidity on propensity to pay dividend are robust across two other alternative 


\section{Rahmat Setiawan \\ Nova Christiana \\ Sanju Kumar Singh}

measures of stock liquidity, HSLE and LOT. This result is consistent with previous results; stock liquidity impacts the propensity to pay dividend. This paper has contributed to fast-growing literature of dividend policy in the agency problem framework. Specifically, the paper aimed to give insight about the Indonesian market for the investors. However, this paper still has some limitations. The result will give a better insight if the study is conducted using bigger data set with longer series, but due to the stock liquidity data availability and the lack of completeness of firms' financial and annual reports, this research was capped at 254 firms as samples.

\section{REFERENCES}

Alan, S. N., Bildik, R., and Schwartz, R. A. 2009. Market microstructure in emerging and developed markets: Microstructure of equity markets. Editor: Baker H.K, and Kiymaz, H. pp: 18. John Willey \& Sons Inc., Hoboken, New Jersey.

Allen, F., Bernardo, A. E., and Welch, I. 2000. A theory of dividends based on tax clienteles. The Journal of Finance 55 (6): 2499-2536.

Allen, F. and Michaely, R. 2003. "Payout Policy", In: Constantinides, G, Harris, M., Stulz, R. (Eds.), Handbook of the Economic of Finance. Editors: G.M. Constantinides, M.Harris, and R.Stulz (1): 337-429, Amsterdam: Elsevier.

Amihud, Y. 2002. Illiquidity and stock returns: Cross-section and time-series effects. Journal of Financial Markets 5: 31-56.

Attig, N., Fong, W., Gandhoum, Y., and Lang, L. H. P. 2006. Effects of large shareholding on information asymmetry and stock liquidity. Journal of Banking and Finance 30: 28752892.

Bae, K., Kang, J., and Kim, J. 2002. Tunneling or value added? Evidence from mergers by Korean business groups. Journal of Finance 57 (6): 2695-2740.

Banerjee, S., Gatchev, V. A., and Spindt, P. A. 2007. Stock market liquidity and firm dividend policy, The Journal of Financial and Quantitative Analysis 42 (2): 369-397.

Barclay, M. J., Smith, C. W., and Watts, R. L. 1995. The determinants of corporate leverage and dividend policies. Journal of Applied Corporate Finance 7 (4): 4-19.

Becker, C. L., Defond, M. L., Jiambalvo, J., and Subramanyam, K. R. 1998. The effect of Audit on Earnings Management. Contemporary Accounting Research 15 (1): 1-24.

Bhattacharya, S. 1980. Nondissipative signaling structures and dividend policy. Qualitative Journal of Economics 95 (1): 1-24.

Black, F. 1976. The dividend puzzle. The Journal of Portfolio Management Winter 2 (2): 5-8.

Chen, D., Jian, M., and XU, M. 2009. Dividens for tunneling in a regulated economy: The case of China. Pacific-Basin Finance Journal 17: 209-223. 
Claessens, S., Djankov, S., Fan, J. P., and Lang, L. H. 2000. Expropriation of minority shareholders in East Asia. Journal of Financial Economics 58: 81-112.

Claessens, S., Djankov, S., Fan, J. P., and Lang, L. H. 2002. Disentangling the incentive and entrenchment effects of large shareholdings. Journal of Finance 57(6): 2741-2771.

Claessens, S. \& Fan, J. P. 2002. Corporate governance in Asia: A survey. International Review of Finance 3 (2): 71-103.

Cooper, S. K., Groth, J. C., and Avera, W. E. 1985. Liquidity, exchange listing, and common stock performance. Journal of Economics and Business 37: 19-33.

Corwin, S. and Schultz, P. 2012. A simple Way to estimate bid-ask spreads from daily high and low prices. The Journal of Finance 67(2): 719-760.

DeCesari, A. 2012. Expropriation of minority shareholders and payout policy. The British Accounting Review 44 (4): 207-220.

Denis, D. J. and Osobov, I. 2008. Why do firms pay dividends? International evidence on the determinants of dividend policy. Journal of Financial Economics 89 (1): 62-82.

Deshmukh, S. 2005. The effect of asymmetry information on dividend policy. Quarterly Journal of Business and Economics 44 (1/2): 107-127.

Duygun, M., Guney, Y. and Moin, A. 2018. Dividend policy of Indonesian listed firms: The role of families and the state. Economic Modelling 75: 336-354.

Easterbrook, F.H. 1984. Two Agency-Cost Explanations of Dividends. The American Economic Review, 74, 650-659.

Edwards, J. 1984. Does dividend policy matter? Fiscal Studies 5 (1): 1-17.

Faccio, M., Lang, L. H. P., and Young, L. 2001. Dividends and expropriation. The American Economic Review 91 (1): 54-78.

Fafatas, S. A. and Sun, K. J. 2010. The relationship between auditor size and audit fees: further evidence from big four market shares in emerging economies. Research in Accounting in Emerging Economies 10: 57-85.

Fama, E. F. and French, K. R. 1998. Taxes, financing decisions, and firm value. The Journal of Finance 53 (3): 819-843.

Fama, E. F. and French, K. R. 2001. Disappearing dividends: Changing firm characteristics or lower propensity to pay?" Journal of Financial Economics 60: 3-44.

Fan, J. and Wong, T. J. 2002. Corporate ownership structure and the informativeness of accounting earnings in East Asia. Journal of Accounting and Economics 33: 401-425.

Gomes, A. 1996. The dynamics of stock prices, manager ownership, and private benefits of control. Harvard University Working Paper.

Gomes, A. 2000. Going public without governance: Managerial reputation effects. The Journal of Finance 55 (2): 615-646.

Gugler K, and Yurtoglu, B. B. 2003. Corporate governance, dividend pay-out policy in Germany. European Economic Review 47: 731-758. 


\section{Rahmat Setiawan \\ Nova Christiana \\ Sanju Kumar Singh}

Guo, J. (2016). Ultimate controlling shareholder and dividend payout policy in Chinese stock market. Review of Pacific Basin Financial Markets and Policies 19 (2): 1-35.

Hoda, T. and Uno, J. 2011. Liquidity, ownership structure, and market share repurchase: Evidence from Japan. Available at SSRN. http://dx.doi.org/10.2139/ssrn.1914152. Accessed 25 June 2019.

Holmstorm, B. and Tirole, J. 1993. Market Liquidity and performance monitoring. Journal of political Economic 101 (4): 678-709.

Huang, J. J., Shen, Y., and Sun, Q. 2011 . Nonnegotiable shares, controlling shareholders, and dividend payments in China. Journal of Corporate Finance 17: 122-133.

Jensen, M. and Meckling, W. 1976. Theory of the firm: managerial behavior, agency costs, and ownership structure". Journal of Financial Economics 3 (4): 305-360.

Jensen, M. C. (1986). Agency costs of free cash flow, corporate finance, and takeovers. The American Economic Review 76 (2): 323-329.

Jiang, F., Ma, Y. and Shi, B. 2017. Stock liquidity and dividend payouts, Journal of Corporate Finance 42: 295-314.

John, K. and Williams, J. 1985. Dividends, dilution and taxes: A Signaling equilibrium. Journal of Finance 40: 1053-1070.

Kyle, A. S. 1984. Market Structure, information, future markets, and price formation. In: Storey, G.G., Schimitz, A., Sarris, A. (Eds), International Agricultural Trade: 45-64. Colorado: Westview Press.

Kyle, A. S. 1985. Continuous auctions and insider trading. Econometrica 53 (6): 1315-1335.

Lang, L. H. P. and Litzenberger, R. H. 1989. Dividend announcements. Cash flow signaling vs. free cash flow hypothesis? Journal of Financial Economics 24 (1): 181-191.

La Porta, R., Lopez-De-Silanes, F., Shleifer, A. and Vishny, R. W. 1999. Corporate ownership around the world. Journal of Finance 54 (2): 471-517.

La Porta, R., Lopez-De-Silanes, F., Shleifer, A. and Vishny, R. W. 2000a. Agency problems and dividend policies around the world. Journal of Financial Economics 55 (5): 1-33.

La Porta, R., Lopez-De-Silanes, F., Shleifer, A. and Vishny, R. W. 2000b. Investor protection and corporate governance, Journal Finance Economics 58 (1): 3-27.

Lesmond, D., Ogden, J. and Trzcinka, C. 1999. A new estimate of transaction costs. The Review of Financial Studies 12 (5): $1113-1141$.

Lesmond, David A. 2005. Liquidity of emerging market. Journal of Financial economics 77 (2): 411-452.

Li, K. and Zhao, X. 2008. Asymmetric information and dividend policy. Financial Management 37 (4): 673-694.

Lin, T. J., Chen, Y. P., and Tsai, H. F. 2017. The relationship among information asymmetry, dividend policy, and ownership structure. Finance Research Letter 20 (C): 1-12. 
Litzenberger, R. and Ramsaswamy, K. 1982. The effects of dividends on common stock price: tax effects or information effects? Journal of Financial 37 (2): 429-443.

Lipson, C. 2003. Reliable Partners: How Democracies Have Made a Separate Peace. Princeton Univerity Press

Leuz, C., Nanda, D. and Wysocki, P. D. 2003. Earnings management and investor protection: an internal comparison. Journal of Financial Economics 69 (3): 505-527.

Luo, J. H., Li, X., and Chen, H. 2018. Annual report readability and corporate agency costs. China Journal of Accounting Research. http://doi.org/10.1016/i.cjar.2018.04.001 .

Michaely, R. and Qian, M. 2016. Stock Liquidity and dividend policy: Dividend policy changes following and exogenous liquidity shock. Available at SSRN. https://ssrn.com/abstract=2894164. Accessed 15 June 2019

Mitton, T. 2002. A Cross-firm analysis of the impact of corporate governance on the East Asian financial crisis. Journal of Financial Economics 64: 215-41.

Mitton, T. 2004. Corporate governance and dividend policy in emerging markets. Emerging Markets Review 5: 409-426.

Miller, M. H. and Rock, K. 1985. Dividend policy under asymmetric information. Journal of Finance 40: 1031-1051.

Miller, M. and Modigliani, F. 1961. Dividend policy, growth, and the valuation of Shares. Journal of Business 34: 411-433.

Mulyani, E., Sigh, H., and Mishra, S. 2016. Dividends, leverage and family ownership in the emerging Indonesian market". Journal of International Financial Markets, Institutions \& Money 43: 16-29.

Petrasek, L. 2012. Do transparent firms pay out more cash to shareholders? Evidence from international cross-listings. Financial Management 41: 615-636.

Rhee, S.G. and Wang, J. 2009. Foreign institutional ownership and stock market liquidity: Evidence from Indonesia. Journal of Banking and Finance 33: 1312-1324.

Rozeff, M. S. 1982. Growth, beta and agency cost as determinants of dividend payout ratios. Journal of Finance Research 5(3): 249-259.

Saadi, S. and Dutta, S. 2011. Tax and clientele effects. In. H.Kent Baker \&HalilKiymaz (Eds.), Dividends and dividend policy: 127-144. New Jersey: John Wiley \& Sons, Inc.

Sari, R. C., and Baridwan, Z. 2014. Current asset tunneling and firm performance in an emerging market. JurnalAkuntansidanKeuangan Indonesia 11 (2): 165-176.

Sawitri, A. N. and Sulistyowati, C. 2018. Stock liquidity and dividend policy In the 2018 International Conference of Organizational Innovation, KnE Social Sciences: 1192-1202. DOI 10.18502/kss.v3i10.3461

Setiawan, D., Bandi, B., Phua, L. K. and Trinugroho, I. 2016. Ownership structure and dividend policy in Indonesia". Journal of Asia Business Studies 14 (5/6): 135-143. 
Smith, C. W. and Watts, R. L. 1992. The investment opportunity set and corporate financing, dividend, and compensation policies. Journal of Financial Economics 32 (3): 263-292.

Stiglitz, Joseph E. 2000. The contributions of the economics of information to twentieth century economics", The Quarterly Journal of Economics 115 (4): 1441-1478.

Strerenczak, S. 2016. Stock market liquidity and company decision to pay dividends: evidence from Warsaw Stock Exchange. In: Choudhry, T. and Mizerka, J. Contemporary Trends in Accounting, Finance and Financial Institutions. Springer Proceedings in Business and Economics: 27-42. Switzerland: Springer International Publishing AG.

U.S. Senate. 2002. The role of the board of directors' Enron's collapse. Report prepared by the Permanent Subcommittee on Investigation of the Senate of the United States.

\section{Appendix 1}

Mariginal Effect Probit Estimation (at means)

\begin{tabular}{ccccccc}
\hline & Margin & $\begin{array}{c}\text { Delta Method } \\
\text { Std. Err. }\end{array}$ & $\mathbf{z}$ & $\mathbf{P}>\mathbf{z}$ & [95\% Conf. & Interval] \\
\hline ccons & 0.517 & 0.016 & 32.37 & 0.000 & 0.486 & 0.549 \\
\hline
\end{tabular}

